\title{
Potential for Sustainable Aquaculture: Insights from Discrete Choice Experiments
}

\author{
Bui Bich Xuan ${ }^{1,2}$ (D) Erlend Dancke Sandorf ${ }^{3}$
}

Accepted: 26 July 2020 / Published online: 4 August 2020

(c) The Author(s) 2020

\begin{abstract}
The growth in global aquaculture production may address the lack of sustainability in wild fisheries, alleviate poverty in rural and coastal areas, and help meet the worldwide increase in demand for animal protein. However, there is an ongoing debate about the severity of the environmental impact of aquaculture production. Investing in new high-tech production systems can address both productivity growth and the environmental externalities, but high investment costs hinder adoption of high-tech production methods. We investigate the potential of a payment for environmental services program easing access to capital for producers to increase willingness-to-invest in more sustainable aquaculture practices in Vietnam. We conducted two discrete choice experiments to explore the supply and demand side of the policy. First, we elicited the public's willingness-to-pay to reduce the environmental impact of conventional shrimp aquaculture, and second, we elicited farmers willingness-toaccept a credit subsidy to invest in high-tech production methods. Our results show that the public care about reduced environmental impacts, while farmers strongly prefer increased productivity. Furthermore, the public's willingness-to-pay for reduced environmental impacts exceeds producer's willingness-to-accept a subsidy to invest under most scenarios. This implies a potential for more sustainable aquaculture production in Vietnam.
\end{abstract}

Keywords Discrete choice experiment · Externalities $\cdot$ High-tech production $\cdot$ Shrimp aquaculture $\cdot$ Sustainability

\section{Introduction}

The growth in global aquaculture production has significantly contributed to addressing the lack of sustainability in wild fisheries, helped meet the worldwide increase in demand for animal protein (FAO 2019), and has become a source of income for rural and coastal communities, especially in developing countries (Klinger and Naylor 2012). Developing

Bui Bich Xuan

xuanbb@ntu.edu.vn

1 Nha Trang University, 02 Nguyen Dinh Chieu, Nha Trang, Vietnam

2 UiT The Arctic University of Norway, 9037 Tromsö, Norway

3 Economics Division, Stirling Management School, University of Stirling, Stirling FK9 4LA, UK 
countries account for $88 \%$ of worldwide aquaculture production (Klinger and Naylor 2012; Engle et al. 2017). However, there is an ongoing debate about the severity of the environmental impacts of aquaculture production on water quality, coastal habitats and ecosystems, and the salinization of groundwater (Páez-Osuna 2001; Senarath and Visvanathan 2001; Jackson et al. 2004; Trai et al. 2007; Anh et al. 2010; Bui et al. 2013; Ha et al. 2014; Pham et al. 2018). The cost of these negative externalities are borne by society and felt keenly by the aquaculture producers, given the negative impact of pollution on production possibilities (Neiland et al. 2001; Edwards 2015). A key challenge facing the industry is to reduce the externalities of production and move towards more sustainable production practices.

A promising (and achievable) path to sustainability is the adoption of high-tech aquaculture production methods. These production methods use less land, less water by recirculating, and have fewer nutrients and chemicals in the run-off as a result of wastewater treatment (Klinger and Naylor 2012). High-tech methods allow farmers to increase production while at the same time reduce the environmental impacts (Klinger and Naylor 2012; Engle et al. 2017). Research suggests that producers are willing to adopt sustainable production practices (Georgakopoulos and Thomson 2005; Lasner and Hamm 2011; Perdikaris et al. 2016), and that there are potential economic benefits from doing so, e.g. sustainable products fetch a price premium in the market (Budak et al. 2006; Olesen et al. 2010; Hinkes and Schulze-Ehlers 2018), but the rate of adoption is still very low, especially in developing countries (Klinger and Naylor 2012; Engle et al. 2017). The main barrier to adopting sustainable aquaculture practices relates to the high investment and operating costs (Klinger and Naylor 2012; Ngoc et al. 2016a; Engle et al. 2017). For example, in Vietnam, which is our case study, suppliers of aqua-feeds, aquatic animal drugs and production facilities are the major sources of funding for aquaculture investment and they charge interest rates of up to $20 \%$ of the investment cost.

To encourage sustainable production, farmers could be provided an economic incentive to change their production practices. One potential useful policy tool that has had some traction in promoting sustainability in fisheries and agriculture, especially in developing countries, is the use of credit subsidies (Pomeroy et al. 2009; Garrity et al. 2010; Pretty et al. 2011; Cisneros-montemayor et al. 2013, 2016; Pan et al. 2016). The source for capital to cover the cost of the subsidy scheme should come from the government or so-called payments for environmental services (PES) schemes. PES schemes call on the people who benefit from environmental services to bear the cost and generate the funds to pay those who provide the environmental services. Effectively incentivizing environmental protection, PES schemes are considered well suited to address the environment-related issues in developing countries with limited national resources (Barr and Mourato 2009). While the potential application of these payment schemes are mostly studied in the forestry, agriculture, watershed ecosystems and marine resources literatures, to the best of our knowledge, evidence of the feasibility of these payment schemes for sustainable aquaculture is nonexistent (Espinosa-Goded et al. 2010; Kaczan et al. 2013; Yeboah et al. 2015; Xuan et al. 2017). Except for Barr and Mourato (2009), these studies focus on assessing the potential for PES schemes mostly through either looking at willingness-to-pay (WTP) for an environmental improvement or a willingness-to-accept (WTA) compensation for not implementing a policy. Rarely have both sides of a policy been considered in the same study.

In this study, we investigate the potential for a PES market for sustainable shrimp aquaculture development in Vietnam. Specifically, we conducted two discrete choice experiments (DCEs) to analyze the supply and demand side of a policy aiming to increase investment in high-tech shrimp aquaculture, i.e. government offers a credit subsidy through 
government backed low-interest rate year-loans for investing in high-tech production. First, we identify the level of preferential interest rate that farmers are willing to pay for a year loan to invest in high-tech production. Then we work out the size of the subsidy, i.e. the cost of the program, by looking at the difference between the market rate and the estimated interest rate. The total cost of the program varies depending on the size of the subsidy and how many acres of land used for shrimp aquaculture is converted to high-tech production practices. Second, we identify how much the general public is willing to pay for a sustainable shrimp aquaculture program that seeks to reduce wastewater discharge and antibiotic use in production. It is assumed that the public's financial support will be used to supplement the costs of the program. We then determine whether this required cost could be met by the public's WTP for the program. We find that for most scenarios, people's WTP exceeds the cost of the subsidy program. Information on farmer's WTA and the public's WTP for a sustainable aquaculture policy that could improve the environment is crucial for policy makers seeking to implement effective policy. The results imply that there are social welfare gains to be had by building environmental regulation. We believe that exploring both the supply and demand side of a policy is a novel contribution to the literature on using DCEs in developing countries.

The rest of this paper is organized as follows: In Sect. 2, we provide a brief review of shrimp aquaculture industry in Vietnam; in Sect. 3, we present the data and econometric approach; in Sect. 4, we present the results; and in Sect. 5 we provide some general discussion of our results and a few policy implications and avenues for future research.

\section{Background of Shrimp Aquaculture Industry in Vietnam}

Vietnam is one of the five largest shrimp producers in the world (Weimin 2017), but is now faced with environmental challenges such as mangrove degradation due to the conversion of mangrove forest to shrimp farms, deteriorating soil quality, water pollution, and disease outbreaks which have resulted in high crop failure rates (Ha et al. 2014; DAH 2017). To reduce the risk of crop failure, Vietnamese farmers began using large amounts of antibiotics and pesticides in production (Anh et al. 2010). Ironically, the measures taken to reduce crop failures are themselves contributing factors to the high crop rate failure, since water source and wastewater are taken and discharged into the same water body for many smallscale farmers. The wastewater from production has high concentrations of nitrogen and phosphorous, and when discharged directly into the water source leads to oxygen reduction and eutrophication (Trai et al. 2007; Bui et al. 2012). When this same water is used as source water for the next shrimp crop, the farmer is forced to use more pesticides and antibiotics to increase his chances of a successful crop. Moreover, it becomes a classical tragedy of the commons situation (Hardin 1968), where no individual farmer has the incentive to reduce the use of pesticides and antibiotics if the neighbors do not reduce theirs as well. To see the scale of the problem, the shrimp aquaculture industry consists predominantly of millions of small-scale household producers (less than 1.0 ha per shrimp farm) spread over 30 provinces, which makes it difficult to manage and monitor breeding grounds, reduce wastewater discharge and run-off, and limit the spread of disease (MARD 2017).

To address both production growth and environmental externalities, the Vietnamese Ministry of Agriculture and Rural Development (MARD) has developed plans to promote white legged shrimp farmer's use of sustainable intensive high-tech production methods (MARD 2017). In recent years, there have been some medium and large scale white-legged 
shrimp farmers who have adopted high-tech production methods and have reported higher economic efficiency (Hai 2017; Thao 2017). However, the rate of high-tech method adoption is very low, i.e. only $1.8 \%$ of shrimp farming areas adopted high-tech methods in the $\mathrm{Ca}$ Mau province which is the most developed area in terms of shrimp aquaculture in Vietnam (Ca Mau DARD 2017). The main barriers to implementation are high investment costs, uncertainty about the performance of high-tech farming methods as well as the possible price premium attached to sustainable aquaculture products, and a lack of access to capital (Ngoc et al. 2016a; Han 2017).

\section{Methods}

\subsection{Survey Design}

To test our hypotheses, we conducted two DCEs to elicit farmers' and the public's preferences for a policy aimed at easing access to investment capital for farmers with the purpose of changing the production methods from conventional to high-tech in white-legged shrimp production. Conventional white-legged shrimp production is characterized by semi-intensive and intensive production, large volumes and frequent water exchange, high use of antibiotics and chemicals, and high risk of disease outbreaks. A DCE is a stated preference method commonly used to estimate non-marketed costs and benefits associated with changes in environmental policy (Hanley et al. 2001; Bennett and Balcombe 2012). DCEs have their foundations in Lancastrian consumer theory, welfare economics and random utility theory, which makes them ideally suited to estimate welfare changes resulting from changes in non-marketed services such as environmental quality (Lancaster 1966; McFadden 1974). In a DCE, respondents are faced with a sequence of choices between competing policy alternatives described by several attributes taking on a finite number of levels. Researchers can then analyze the responses to the experimentally designed alternatives under the assumption that respondents choose their utility maximizing alternative in each choice task. This allows the researcher to estimate the utility function up to a probability, and derive welfare measures such as famers' marginal WTP a low-interest rate for a year loan to invest in high-tech production, and the public's WTP a higher tax to obtain an improvement of environment.

To obtain good WTP estimates it is crucial that the attributes and levels reflect reality and that both are perceived as realistic and relevant by respondents. The attributes and levels included in our discrete choice experiments were determined based on consultation with experts in shrimp aquaculture and local government officials, environmental economists at Nha Trang University, and previous studies (see e.g. Bosma et al. 2012; Ngoc et al. $2016 \mathrm{a}, \mathrm{b})$. To test the relevance of the attributes to respondents, we conducted several focus groups with both farmers and the general public.

In the producer DCE, we asked farmers to choose between two experimentally designed investment alternatives described by four attributes and an opt-out alternative defined as "I would not invest and stay with my current production method". We provide an overview of the attributes and levels in Table 1. Since shrimp farmers can set multiple crops per year and the number of crops and farm size varies between farmers, we define all changes of production in percent on a per crop basis. Moving from conventional to high-tech production methods is expected to have higher yield per crop. We however included both positive and negative change in yield, the latter is to capture the uncertainty about the performance 
Table 1 Attributes and levels used in the two DCEs

\begin{tabular}{|c|c|c|}
\hline Attribute & Description & Levels and codes \\
\hline \multicolumn{3}{|l|}{ Farmer } \\
\hline Yield & A change in yield per crop & $\begin{array}{l}-20 \%=\text { large decrease in yield; } \\
-10 \%=\text { small decrease in } \\
\text { yield; } 0^{\text {b }} ;+10 \%=\text { Small } \\
\text { increase in yield; } \\
+20 \%=\text { large increase in yield }\end{array}$ \\
\hline Crop & Additional crop per year & $0 ; 1$ \\
\hline Environment & $\begin{array}{l}\text { Average percentage of water exchanged per } \\
\text { crop }\end{array}$ & $10 \% ; 15 \% ; 20 \% ; 25 \% ; 30 \%$ \\
\hline Preferential interest rate & Interest rate for a year loan & $4.2 \% ; 5.2 \% ; 6.2 \% ; 7.2 \% ; 8.2 \%$ \\
\hline \multicolumn{3}{|l|}{ Public } \\
\hline Food safety & Food safety standard & $\begin{array}{l}0=\text { the controlled use of antibi- } \\
\text { otics following the government } \\
\text { standard } 2625 / \mathrm{B} \text {-BNN-TY; } \\
1=\text { no use of antibiotics, but } \\
\text { use of probiotics }\end{array}$ \\
\hline Environment & $\begin{array}{l}\text { Average percentage of water exchanged per } \\
\text { crop }\end{array}$ & $10 \% ; 15 \% ; 20 \% ; 25 \% ; 30 \%$ \\
\hline $\operatorname{Cost}^{\mathrm{a}}$ & $\begin{array}{l}\text { Surcharge on monthly electricity bills, paid } \\
\text { for } 5 \text { years (thousand VND) }\end{array}$ & $20 ; 40 ; 60 ; 80 ; 100$ \\
\hline
\end{tabular}

${ }^{\mathrm{a}}$ At the time of the survey: USD $1=$ VND 23,202

${ }^{\mathrm{b}}$ Based reference

of new methods due to the system complexity as well as experience, knowledge and management skill of farmer (Ngoc et al. 2016a; Engle et al. 2017). Using conventional methods, a shrimp farmer can have 1-2 successful crops per year but using high-tech production methods he may get 2-3 successful crops per year. We define the additional crop attribute to take on two levels: 0 or 1 additional crop per year. High-tech production can reduce the water exchange during a production cycle dramatically compared to the conventional method. Finally, to ease access to capital, the government is offering a credit subsidy in the form of a government backed low-interest rate year loan. The interest rate for this year loan is lower than the market rate of $8.2 \%$.

In the public DCE, we asked people to choose between two experimentally designed policy alternatives described by three attributes and an opt-out alternative defined as: "I would not support the proposed policy". We provide an overview of the attributes and levels in Table 1. The first attribute covers food safety. Conventional shrimp farming is characterized by high use of pesticides and antibiotics in production, which may affect food safety. High-tech production methods on the other hand use significantly less antibiotics and in some cases no antibiotics at all. The second attribute is an environmental attribute described by the water exchange per crop. This is the most salient measure of environmental impact. To ensure comparability between the two DCEs, this attribute was framed in the same way as for farmers. While this attribute is perfectly understandable to farmers, it may not be to the public. To make clear the connection between the attribute and environmental quality, respondents were told that the greater the amount of water exchanged during the shrimp production cycle, the higher the risks of polluting nearby water sources. Furthermore, our enumerators were able to provide additional clarification if needed. As such, we are reasonably confident that respondents understood the connection between water 
exchange and changes in environmental quality. Improvements in the level of both attributes come as a result of shrimp farmers investing in high-tech production methods. The increased investments are linked to the credit subsidy policy that eases access to capital, the cost of which, must be borne by the public. The cost attribute is defined as a surcharge on a household's monthly electricity bill, in Vietnamese Dong (VND), paid for 5 years. It is suggested that the electricity bill is the best choice for the payment vehicle in Vietnam because of its coverage and compulsory nature (Do and Bennett 2009).

For both DCEs, we combined the attributes and levels into a Bayesian D-efficient experimental design optimized for the multinomial logit model (Scarpa and Rose 2008). We updated the designs based on priors obtained from pilot studies. For each DCE, the final design comprised 15 choice tasks that were blocked into three blocks of five choice tasks each. Respondents were randomly allocated to one of the blocks. To limit ordering effects, the order of the choice tasks was rotated between respondents. We present translated sample choice tasks in Tables 2 and 3 for the farmer and public DCEs respectively.

Each survey questionnaire consisted of the following six parts: (1) a brief introduction explaining the purpose of the survey, including a brief description of the two shrimp farming practices, i.e. conventional and high-tech, focusing on the features of production, wastewater discharge, antibiotic use, and environmental impacts; (2) a background section seeking to explore the public's consumption behavior, and the farmers' current aquaculture production methods; (3) a section trying to elicit the public's and farmers' perceptions and attitudes towards conventional shrimp aquaculture; (4) a section containing a brief introduction to the discrete choice experiment and the choice tasks; v) a section eliciting reasons for peoples choices; and, (6) a section gathering socio-demographics. In the public DCE survey, we also included a cheap talk script with the purpose of reducing hypothetical bias (Lusk 2003).

\subsection{Sampling and Sample Composition}

The data was gathered in March and April of 2019 using face-to-face interviews. All questionnaires were administered, and all interviews were conducted, in Vietnamese using local enumerators and with the help of local aquaculture officers. A sample of 205 shrimp farmers was randomly selected based on the lists of shrimp farmers provided by the Aquaculture Department in the four Vietnamese provinces of Khanh Hoa, Ninh Thuan, Soc Trang and Bac Lieu. Together, these four provinces cover $49 \%$ of the area used for white-legged shrimp farming (MARD 2017). We conducted another set of face-to-face interviews with a random sample of 270 people representing the general public in the Khanh Hoa province and Ho Chi Minh City (HCMC). These interviews took the form of household surveys. We selected Khanh Hoa because it is a representative province in south-central Vietnam given that it is a typical shrimp farming location. HCMC is a large city and representative of southern Vietnam because of its high population density. The main shrimp farming regions are found south of HCMC. We believe that the combination of sampling in the Khanh Hoa province and HCMC gives a good picture of the public's preferences for sustainable aquaculture policy. Especially considering the challenges of conducting large scale face-to-face surveys in a developing country and to get a representative sample in the two regions, we used a random walk and quota sampling procedure. We provide descriptive statistics of key variables in Table 4.

While our public sample matches the general public on gender ( $48 \%$ compared to $49 \%$ ), it is slightly older (40 years compared to 31 ), higher educated (43\% compared 


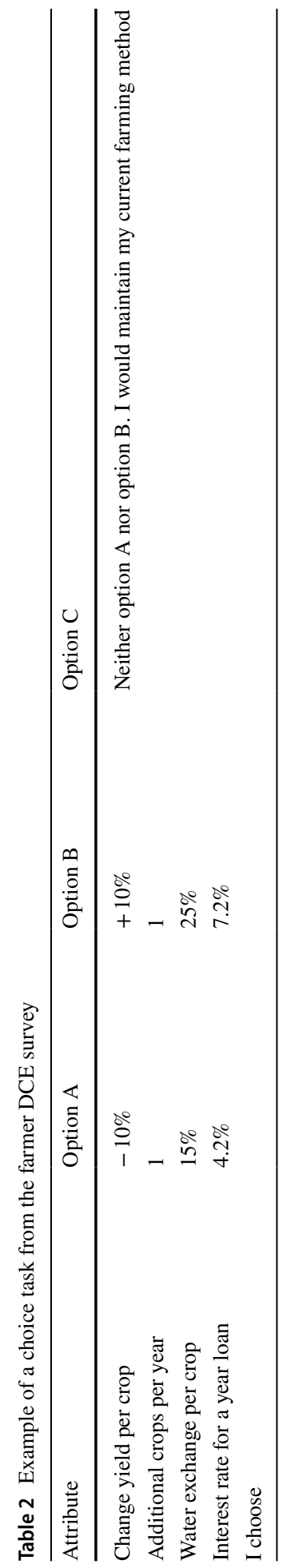


Table 3 Example of a choice task from the public DCE survey

\begin{tabular}{lllc}
\hline Attribute & Option A & Option B & Option C \\
\hline Food safety & $\begin{array}{l}\text { No use of antibiot- } \\
\text { ics, but use of } \\
\text { probiotics }\end{array}$ & $\begin{array}{c}\text { Controlled use of antibiotics follow- } \\
\text { ing the government standard 2625/ }\end{array}$ & $\begin{array}{c}\text { Neither option } \\
\text { A nor option }\end{array}$ \\
& QĐ-BNN-TY & B \\
Water exchange per crop & $15 \%$ & $10 \%$ & \\
Cost (VND 1000/month) & 40 & 60 & \\
I choose & & & \\
\hline
\end{tabular}

Table 4 Sample descriptive statistics

\begin{tabular}{|c|c|c|c|c|}
\hline \multirow[t]{2}{*}{ Variable } & \multicolumn{2}{|l|}{ Famer } & \multicolumn{2}{|l|}{ Public } \\
\hline & Mean & SD & Mean & SD \\
\hline \multicolumn{5}{|l|}{ Socio-demographic characteristics } \\
\hline Male & 0.96 & 0.18 & 0.48 & 0.50 \\
\hline Age & 49.11 & 9.69 & 40.03 & 14.33 \\
\hline Professional education & 0.03 & 0.16 & 0.03 & 0.17 \\
\hline Tertiary education & 0.13 & 0.33 & 0.40 & 0.49 \\
\hline Member of environmental organization & 0.02 & 0.16 & 0.01 & 0.09 \\
\hline Average household income (million VND/month) & 19.58 & 10.41 & 16.23 & 23.66 \\
\hline \multicolumn{5}{|l|}{ Farm's characteristics } \\
\hline Farm size $\left(\mathrm{m}^{2}\right)$ & $14,763.90$ & $10,547.05$ & - & - \\
\hline Yield per crop (ton) & 7.04 & 8.70 & - & - \\
\hline Crop per year (crop) & 2.28 & 0.70 & - & - \\
\hline Average water exchange in pond (\%) & 42.71 & 20.81 & - & - \\
\hline \multicolumn{5}{|l|}{ Public's consumption, knowledge and familiarity } \\
\hline How often do you eat shrimp per month & - & - & 3.31 & 1.94 \\
\hline Heard and understand sustainable aquaculture & - & - & 0.04 & 0.21 \\
\hline Heard of, but do not understand sustainable aquaculture & - & - & 0.47 & 0.50 \\
\hline \multicolumn{5}{|l|}{ Respondent's perception } \\
\hline Economic benefit of high-tech method & 0.89 & 0.31 & 0.78 & 0.41 \\
\hline Applied and expanded high-tech method & 0.92 & 0.28 & 0.87 & 0.34 \\
\hline Personally environmentally conscientious & 0.81 & 0.39 & 0.67 & 0.47 \\
\hline
\end{tabular}

to 22\%), and higher average household income (million VND 16.2 compared to 13.6) than the general public. Our farmer sample is more male dominated, older and lower educated. This is because men take the most responsibility in aquaculture and the interviews often took place with the head of the household. The lower education for farmers can be explained by the nature of shrimp farming in Vietnam. It is small scale, spontaneous and mainly distributed in rural coastal areas where education levels are lower.

To understand better what underpins the public's choices, we elicited information on their knowledge and familiarity with shrimp aquaculture. For example, we asked the question: "Have you heard about sustainable aquaculture?" with the possible responses: "Yes, and I understand what it is", "Yes, but I do not understand what it is" and "No". 
Interestingly, almost half (47\%) of our respondents in the public sample had heard about sustainable aquaculture, but they had no knowledge about what it was before answering the survey. Furthermore, for both samples, we investigated respondents' awareness of sustainable aquaculture production methods using statements such as: "I believe that promoting sustainable shrimp aquaculture practices facilitates long term economic benefits to farmers and society through increased food security." and "I believe that sustainable shrimp aquaculture models should be applied and expanded". Personal environmental conscientiousness was explored through the statement: "I consider myself environmentally conscientious". Responses to these statements were elicited using a five-point Likert scale where 1 was "strongly disagree" and 5 was "strongly agree". In Table 4, we have recoded the responses to be equal to 1 if a respondent said that the "strongly agree" or "agree" to the statements above and zero for the other responses. We see that a large share of both farmers and the public see themselves as environmentally conscientious, and they tend to agree with the statements about the socio-economic and environmental benefits of sustainable high-tech aquaculture production practices as well as the necessity expand the use of such methods.

\subsection{The Econometric Approach}

To introduce notation, we assume that the utility respondent $n$ derives from alternative $i$ in the choice situation $t$ can be expressed as follows:

$$
U_{n i t}=\beta X_{n i t}+\varepsilon_{n i t}
$$

where $\beta$ is a vector of utility weights to be estimated, $X_{\text {nit }}$ a vector of attributes, and $\varepsilon_{\text {nit }}$ a type 1 extreme value distributed error term. Under standard assumptions, the probability that individual $n$ chooses alternative $i$ in choice situation $t$ can be described by the multinomial logit model (MNL) (McFadden 1974):

$$
\operatorname{Pr}(i \mid \beta)=\frac{\exp \left(\beta X_{n i t}\right)}{\sum_{j=1}^{J} \exp \left(\beta X_{n j t}\right)}
$$

The MNL model is still widely used because of its relative simplicity and closed form solution (Ruto and Garrod 2009). However, the assumptions underlying the MNL model implies that people are preference clones, i.e. that scale is equal to unity and that preferences for a given attribute can be described by a single parameter. Furthermore, it rests on the assumption of independence from irrelevant alternatives (Hausman and McFadden 1984), which rarely holds in reality. We relax the assumption of preference homogeneity by assuming that people's preferences can be described by a finite set of distinct values. This will lead to a latent class specification. The benefit of a latent class model over a mixed logit model, is that in the former, we, as researchers, do not have to make any distributional assumptions, but we do have to decide how many support points to include in our discrete distributions (Greene and Hensher 2003; Kaczan et al. 2013). We can estimate the probability that a given respondent's utility weights are described by the vector $\beta_{q}$, i.e. that they are in class $\mathrm{Q}$, as follows:

$$
\pi_{q}=\frac{\exp \left(\gamma_{q} Z_{n}\right)}{\sum_{q}^{Q} \exp \left(\gamma_{q} Z_{n}\right)}
$$


where $\gamma_{q}$ is a class specific vector of parameters to be estimated that can include a constant and $Z_{n}$ is a vector of individual specific variables. The $Q$ th parameter vector is set to zero for identification. We can write the overall log likelihood as:

$$
\operatorname{Pr}\left(y_{n} \mid \beta, X_{n i t}\right)=\sum_{q=1}^{Q} \pi_{q} \prod_{t=1}^{T} \frac{\exp \left(\beta_{q} X_{n i t}\right)}{\sum_{j}^{J} \exp \left(\beta_{q} X_{n j t}\right)}
$$

Notice that the latent class model takes the panel nature of the data into account by taking the product over the sequence of choices made by each respondent. We can calculate sample level WTP as the weighted sum across classes where the weights are the unconditional class probabilities (Eq. 3).

$$
W T P=\sum_{q}^{Q} \pi_{q} \frac{\beta_{q, \text { non-cost }}}{-\beta_{q, \cos t}}
$$

\section{Results}

\subsection{Model Estimates and WTP Calculation}

All models were estimated using the statistical software R. To ensure comparability we use the same model specifications on both datasets. To ease interpretation of our model results, we recoded the levels of the environmental attribute, i.e. the percentage of water exchanged per crop, such that it represented an improvement. In the producer sample, we used farmers' self-reported current levels of water exchange as the baseline, whereas in the public sample, we used the highest water exchange level of the high-tech aquaculture methods (30\%). In the producer sample, we split the yield attribute and defined it as dummies to explicitly consider that people may have different preferences for increases and decreases in yield, as well as possible non-linear response to magnitude. Lastly, we included an interaction term between yield and an additional crop. We believe that people may be willing to accept lower yield per crop if that also involves getting an additional successful crop such that the total yearly yield has gone up. An alternative specific constant (ASC) was included in the utility function of the opt-out alternative in both datasets in order to address any potential opt-out effects (Campbell and Erdem 2019).

In Table 5, we present the estimated results from the MNL and LC models as well as marginal WTP associated with the farmer sample. We present the results of the public survey in Table 6. WTP estimates and 95\% confident intervals (CI) are calculated using the Delta method. It is clear that for both samples, the LC model outperforms the MNL model, implying that people have different preferences, however, we note that part of this increase in explanatory power comes as a result of taking the panel structure of the data into account. We report the results only for the LC model with 2 classes. Moving beyond two classes does lead to improved model fit but is not supported by the BIC statistic. Furthermore, for one of the datasets, we are unable to retrieve the variance-covariance matrix for the three-class model. This is likely because of relatively low variability in the data, i.e. all farmers and everyone in the public appear to have similar preferences in that they prefer to invest or support the policy over sticking with the status quo.

On average, farmers have positive and significant preferences for increased crop and yield. They dislike a reduction in yield, however, they are willing to invest in a project with decreased yield as long as the decrease is offset by an additional crop. Farmers do not seem 


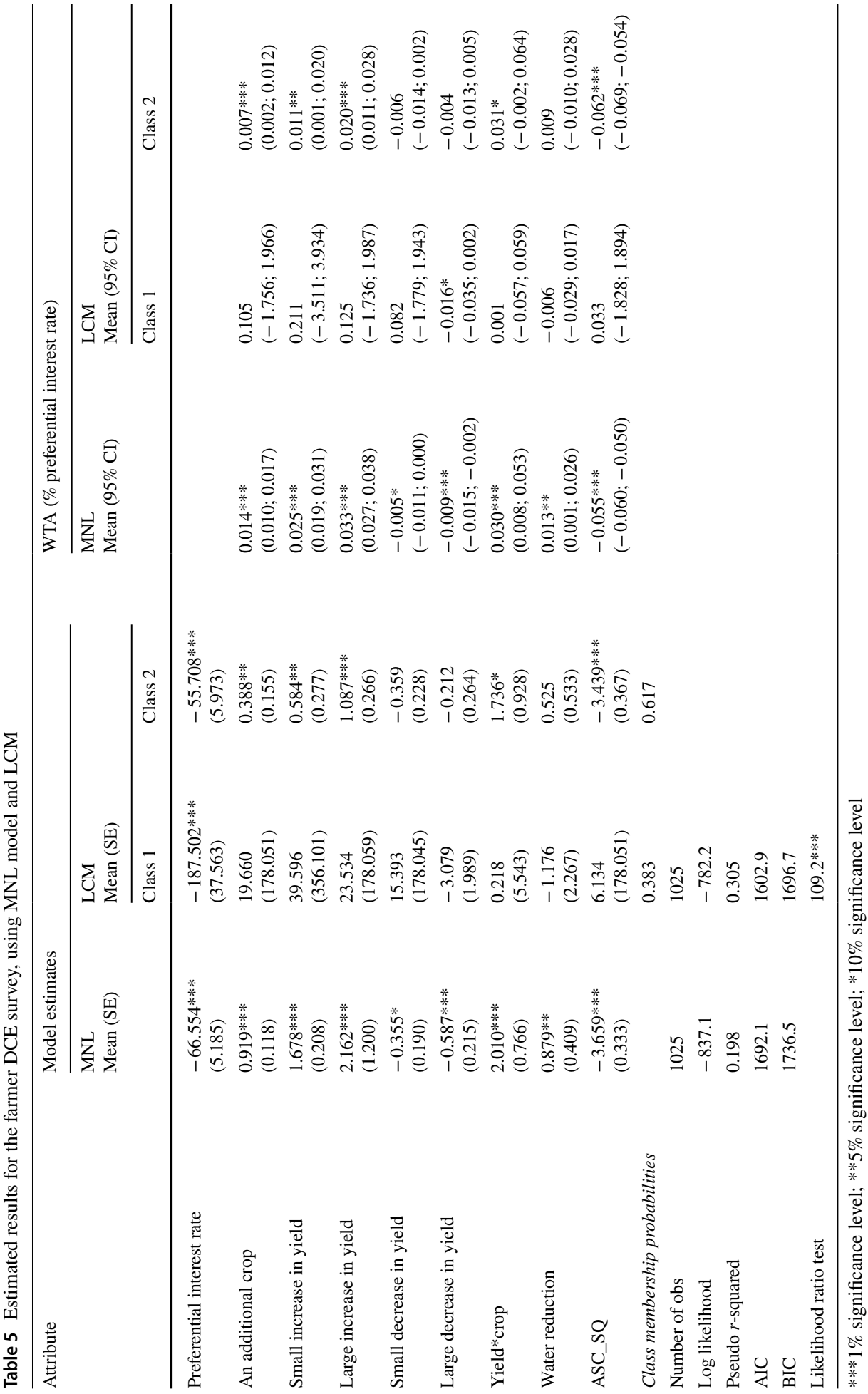


to care about reducing the water exchanged during a production cycle, despite of the fact their production cost (i.e. environmental fees for wastewater discharge and disease costs) can be reduced (internal effects) and the water quality of canals and rivers can be improved (external effects). It is possible that given the high failure rate of crops, having successful crops and higher yields are dominant concerns over the reduction in wastewater discharge.

Turning our attention to the latent class model, we see that class one, with a class probability of $38 \%$, describes respondents who are extremely cost sensitive and tend to choose the status quo, i.e. those that are unwilling to invest in high-tech production methods. All the non-cost parameters in this class are insignificant, which translates into insignificant willingness-to-pay. ${ }^{1}$ It is likely that this class picks up all of the non-traders, i.e. the farmers who chose not to invest in all or almost all of the choice tasks. Famers in class two, with a class probability of $62 \%$, on the other hand, are indeed willing to invest. They are less cost sensitive and have strong and positive preferences for improved productivity and higher yields. They prefer a large increase in yield over a small increase, and they have strong preferences for an additional crop, especially when combined with additional yield. This class mirrors more closely the results obtained from the MNL model. Shrimp farmers in class two are willing to pay a preferential interest rate of $1.1 \%$ and $2 \%$ for a year loan to invest in hightech aquaculture methods if that means they can get an increased yield of $10 \%$ and $20 \%$ respectively. Their WTP for an additional crop is $0.7 \%$ of the preferential interest rate.

Using the information on preferential interest rates, we can calculate what the subsidized interest rate for a year loan would be, and from that extrapolate what the cost of the policy would be. For example, the subsidized interest rate for a year loan required to make an investment would be $7.1 \%(7.1 \%=8.2 \%-1.1 \%), 6.2 \%(6.2 \%=8.2 \%-2 \%)$, and $7.5 \%$ $(7.5 \%=8.2 \%-0.7 \%)$ for $10 \%$ and $20 \%$ increase in yield, and an additional crop, respectively. The WTP preferential interest rate for the relevant attributes of high-tech production are quite low and statistically significant implies a high subsidized interest rate. This indicates that the subsidy, and by extension easier access to capital, is an important factor affecting a shrimp farmer's decision to invest in high-tech production methods.

From Table $6,{ }^{2}$ we see that the public want to support policies that lead to more sustainable aquaculture production methods. The cost parameter is negative and significant as expected. People do not seem to care much about food safety. It could be that as long as the farmer adheres to the government standard on controlled use of antibiotics, the public is indifferent to a situation where there is no use of antibiotics but use of probiotics. In contrast, we have a large and positive preferences for water reduction, i.e. they are more likely to choose an alternative with a larger reduction in water exchange. Results from the latent class model suggests two rather distinct segments. People predicted to be in class 1 have very strong preferences for water reduction and food safety, but they are relatively insensitive to cost. Combined with a slightly positive and significant status quo constant, it suggests that these respondents have chosen alternatives with large reductions in water almost irrespective of the cost. The fact that the cost parameter is insignificant suggests that the

\footnotetext{
1 We confirmed this by calculating the standard error of the actual WTP estimate using the delta method.

${ }^{2}$ We are cognizant of the fact that our public sample consists of older, richer and higher educated individuals. To try and control for the skewness of our sample, we also ran estimations using "population weights". However, due to limited census data availability, we were only able to create weights corresponding to gender, age and education, and not according to income. However, given the correlation between age, education and income, we believe we are capturing a substantial amount of variation. The weighted estimations do not change our conclusions in any substantive way. The only observed changes are in Class 1 where the marginal utility of cost goes from insignificant, to positive and significant, which is counter to economic theory. Class 2 remains of roughly the same size and parameter estimates, and consequently similar marginal WTP. These results are available upon request.
} 


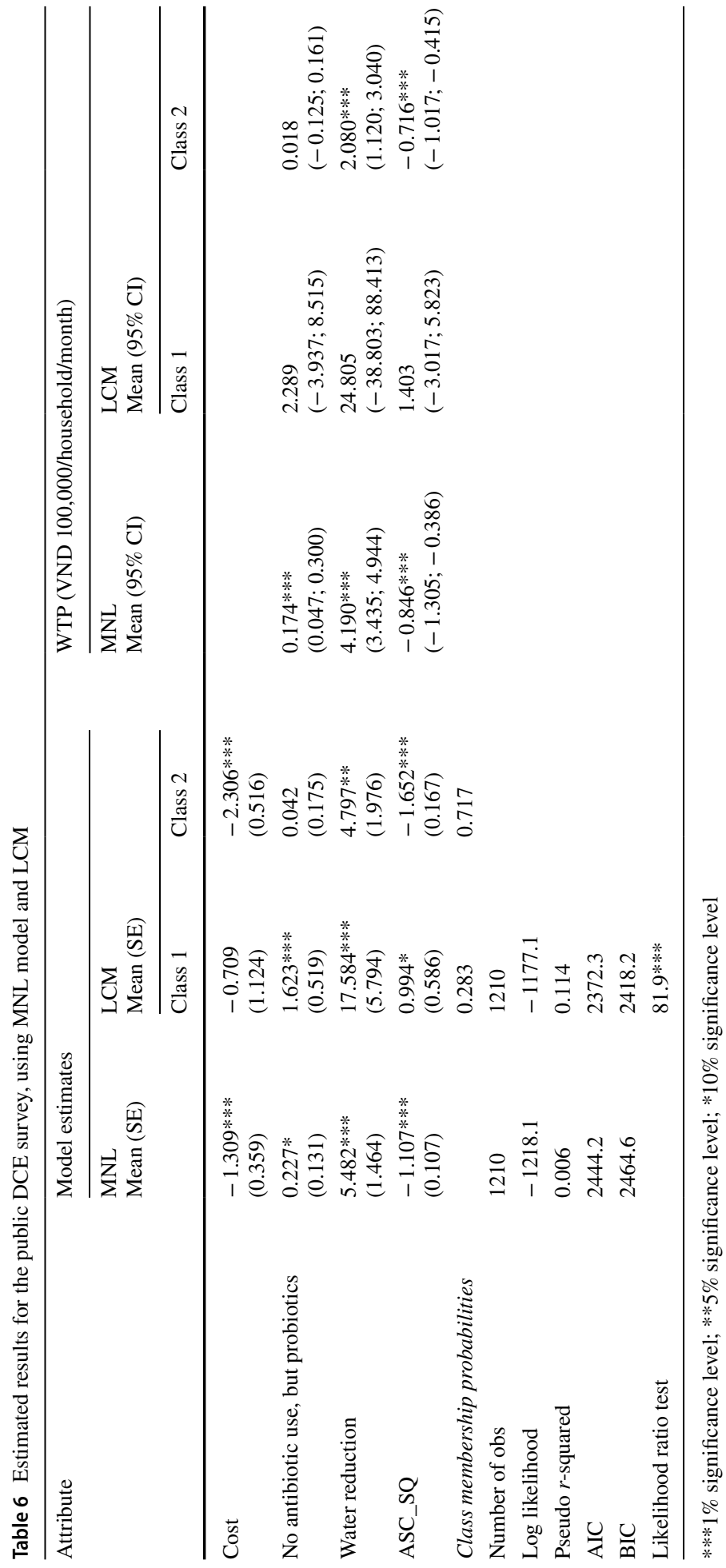


WTP for these individuals is infinite, but statistically insignificant. ${ }^{3}$ As such, it is undefined in our model. People predicted to be in class two, on the other hand, also have strong preferences for water reduction and they are more cost sensitive. The preferences of these individuals are closer to what we observed in the MNL model. For example, they are willing to pay about VND 20,800 (USD 0.9 approximately) per month for 5 years for 10\% reduction in exchanged water during a shrimp production cycle, whereas they are only willing to pay VND 1800 (USD 0.08 approximately) to have production without antibiotics, although this estimate is insignificant. Taken together, these results show that people are indeed willing to pay for the environment. We did run additional models with socio-demographic variables in the class probability functions, but none of these parameters were significant.

We know that farmers are willing to invest in high-tech production if they are offered a subsidy, and we know that the public is willing to pay for a sustainable aquaculture program that reduces the water exchanged during the production cycle. The question then is: Is what the public is willing to pay enough to cover the cost of the subsidy program that will induce farmers to invest?

\subsection{Aggregation of Results}

In this section, we present welfare comparisons using the estimates from the LC models. There appears to be roughly $38 \%$ and $28 \%$ of respondents in the farmer and public datasets that do not make trade-offs and for which the willingness-to-pay estimates are insignificant. In the following analysis, we only use the estimates for the class with significant WTP and weight our calculations accordingly.

In Table 7 we present estimates of the potential aggregate benefits and costs of the proposed policy under various assumptions about the size of the shrimp farming area that is converted to high-tech production practices and various levels of the subsidized interest rate. In 2018, 96,246 ha of the Vietnamese coastal area was used for white-legged shrimp farming (MARD 2017). The estimated investment cost for one hectare of shrimp farming using the recirculating aquaculture systems (RAS), which is the most expensive high-tech farming method, is about six billion Vietnam dong (USD 260,000 approximately) (Ngoc et al. 2016b; Trung Chanh 2018). RAS can be varied in design and construction, but following the key function of wastewater treatment; it was suggested as a potential solution to reduce wastewater discharge and to improve in-pond water quality hence mitigating environmental impacts (Klinger and Naylor 2012). We assume that the white-legged shrimp farming area is converted to RAS production is up to $70 \%$ total coastal area used for shrimp farming in order to make it in corresponding to the class probability of $62 \%$ respondents who were indeed willing to invest in high-tech production. Based on this information, we compute total cost of investment in high-tech production for various area conversions in ten percentage point increments. We then estimate the cost of the credit subsidy program, which is varied from 1 to $7 \%$ subsidized interest rate for a year loan to cover the spread of farmers' willingness-to-accept. Finally, we calculate the benefit to the program as the publics' aggregate WTP for $5 \%, 10 \%$ and $15 \%$ reduction in wastewater discharge over 5 years, based on the information of the mean estimate of wastewater reduction attribute of the LCM, the class probability of $72 \%$ respondents who have significant WTP, and the total of households in Vietnam consuming electricity (26,601,378 households), consisting of 99\% total households in Vietnam in 2018.

With public's aggregate WTP for 5\% wastewater reduction which is billion VND 11,951 (million USD 515 approximately) is sufficient to cover the cost of subsidy up to $7 \%, 6 \%, 5 \%$,

${ }_{3}^{3}$ We confirmed this by calculating the standard error of the actual WTP estimate using the delta method. 


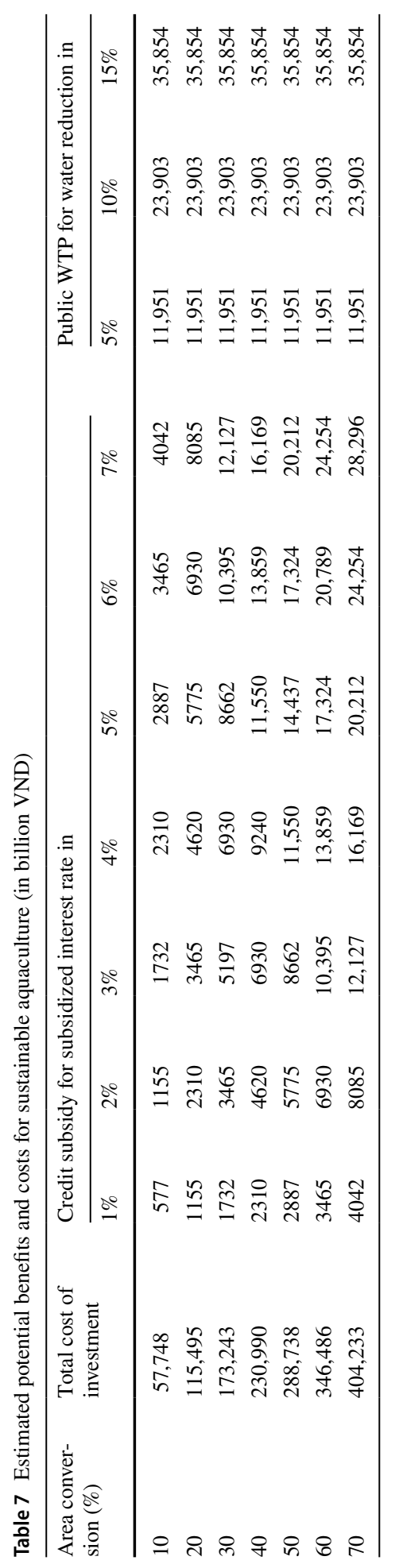


$4 \%, 3 \%, 2 \%$ subsidized interest rate for a year loan corresponding to the converted shrimp farming area of $20 \%, 30 \%, 40 \%, 50 \%, 60 \%$, and $70 \%$, respectively. Whereas, with public's financial support for $10 \%$ wastewater reduction which is billion VND 23,903 (million USD 1030 approximately) is sufficient to cover the cost of subsidy up to $7 \%$ subsidized interest rate for $50 \%$ shrimp farming area conversion. If the subsidized interest rate is $5 \%$ the public's aggregated WTP is sufficient to cover the cost of subsidy for $70 \%$ shrimp farming area conversion. At public's aggregated WTP for 15\% wastewater reduction which is billion VND 35,854 (million USD 1545 approximately), the cost of subsidy up to 7\% subsidized interest rate for $70 \%$ converted shrimp farming area is sufficient covered. We summarize these results in Table 7.

\section{Discussions and Policy Implications}

Production growth in aquaculture is likely to come from intensification of aquaculture production which is commonly accompanied by increased environmental problems and challenges (Hempel et al. 2002). A potential solution to move towards sustainable growth in the future is to change from conventional semi-intensive and intensive production to high-tech aquaculture methods, which allows farmers to intensify production while reducing water consumption as well as nutrient and chemical pollution by treating water and then reusing it (Klinger and Naylor 2012). In this paper, we sought to explore the viability of using a credit subsidy scheme, which is funded via a PES program for 5 years, to induce shrimp farmers to invest in high-tech production methods. We look at both the supply and demand side of the sustainable shrimp aquaculture program and assess whether the benefits, i.e. the public's willingness-to-pay to see the program implemented, exceeds the farmers' willingness-to-accept a credit subsidy to invest in high-tech production, i.e. the costs of the program. We then estimated the costs and the benefits under various assumptions about the amount of semi-intensive and intensive shrimp farming area converted from conventional to high-tech production.

Our results show that under most scenarios, the cost of the credit subsidy program is lower than the public's aggregate WTP, implying the proposed PES scheme has the potential to contribute to shrimp aquaculture sustainability in Vietnam. This result is in contrast to the only other study we are aware of that look at the supply and demand side of a policy similar to this. Barr and Mourato (2009) show that tourists' WTP for environmental improvements in terms of reduced fishing pressure (the demand side) was not enough to compensate the loss of local small scale fishermen (the supply side). This could be related to the natural difference between the groups asked to cover the cost of the policy. Visitors are paying for a marginal environmental improvement in a holiday event-a relative unimportant decision in a wider context (Barr and Mourato 2009), while the public, as in this study, are looking the aspect that is more or less affecting them personally as well as society in general. However, we are cognizant that respondents in our public sample have higher average household incomes compared to the national average, which may inflate our WTP estimate somewhat. To try and control for this, we also ran the estimation with constructed "population weights" for validation, but this did not change our results in a substantive way. Please see footnote 2 and the "Appendix" for details. Furthermore, we explored latent class models with socio-demographic variables in the class probability functions, including income, but the estimates of the marginal effect of household income were insignificant.

It is expected that moving from conventional to high-tech aquaculture production will lead to higher yields and possibly an additional crop. This should encourage profit maximizing shrimp farmers to invest. However, we found that farmers required a substantial subsidy to make the investment in high-tech production methods. In addition, there is also evidence that a significant 
proportion of farmers, roughly $38 \%$ respondents, are unwilling to invest and change from their current production practices. As suggested by Ngoc et al. (2016a, b), there are several possible reasons for this, for example, uncertainty with respect to the performance of new methods, the potential price premium that sustainably produced shrimp may fetch in the market, and lack of access to financing. The findings in the DCE conducted with farmers are robust and consistent with what they told us during the focus groups and interviews. For example, some farmers said that if high-tech production would ensure successful crops, i.e. reduce the number of failed crops, they would not hesitate to make the investment and would even be able to pay up to $12 \%$ interest, which far exceeds the current market rate of $8.2 \%$. One reason is the short production cycle of the white-legged shrimp; with good production conditions, a farmer can produce 3-4 crops per year, as such the return on investment can be high and happen fast. We, therefore, suggest that the subsidy is necessary to offset the potential risks related to the high-tech production investment. That is, the investment may not lead to higher crop success rates because of the failure to undertake complexities associated with new production methods.

A credit subsidy scheme could provide a good incentive to encourage shrimp farmers to invest in high-tech production practices, however, it should only be used in the early stages of technological development to help offset the risk of investment and potentially compensate for losses. In the long term, to increase the rate of technological adoption on farms and to achieve sustainable aquaculture policies, policymakers should target the policy at farmers who are focusing on sustainability. As mentioned above, shrimp farmers may not require the credit subsidy to invest in high-tech production capabilities, and they could, if the new technology leads to higher success rates, pay normal interest rate on capital. However, the investment and operating costs associated with high-tech aquaculture methods are significant, and many farmers, especially small-scale household farmers, may not have enough output to shoulder the cost of investment.

In addition, policymakers should pay attention to the interactive learning between farmers, researchers, extension services, technology providers, and policy-makers in order to reduce the negative outcomes resulting from technological complexities (Kumar et al. 2018). Training and education are necessary to fill the technical knowledge gap that was indicated as a significant obstacle to adopt high-tech methods (Kumar et al. 2018). Ngoc et al. (2016a) indicated that education have positive effect on RAS adoption for pangasius farming in Vietnam. It would also be necessary to encourage all farmers using the same water source to invest to overcome the tragedy of the common's situation currently existing with respect to farmers sharing the same water source.

Acknowledgements Open Access funding provided by UiT The Arctic University of Norway. This research is funded by Vietnam National Foundation for Science and Technology Development (NAFOSTED) under Grant Number 502.99-2018.25. Erlend Dancke Sandorf acknowledges funding from the European Union's Horizon 2020 research and innovation program under the Marie Sklodowska-Curie Grant Agreement No 793,163 (INSPiRE).

Open Access This article is licensed under a Creative Commons Attribution 4.0 International License, which permits use, sharing, adaptation, distribution and reproduction in any medium or format, as long as you give appropriate credit to the original author(s) and the source, provide a link to the Creative Commons licence, and indicate if changes were made. The images or other third party material in this article are included in the article's Creative Commons licence, unless indicated otherwise in a credit line to the material. If material is not included in the article's Creative Commons licence and your intended use is not permitted by statutory regulation or exceeds the permitted use, you will need to obtain permission directly from the copyright holder. To view a copy of this licence, visit http://creativecommons.org/licenses/by/4.0/.

\section{Appendix}

See Table 8. 


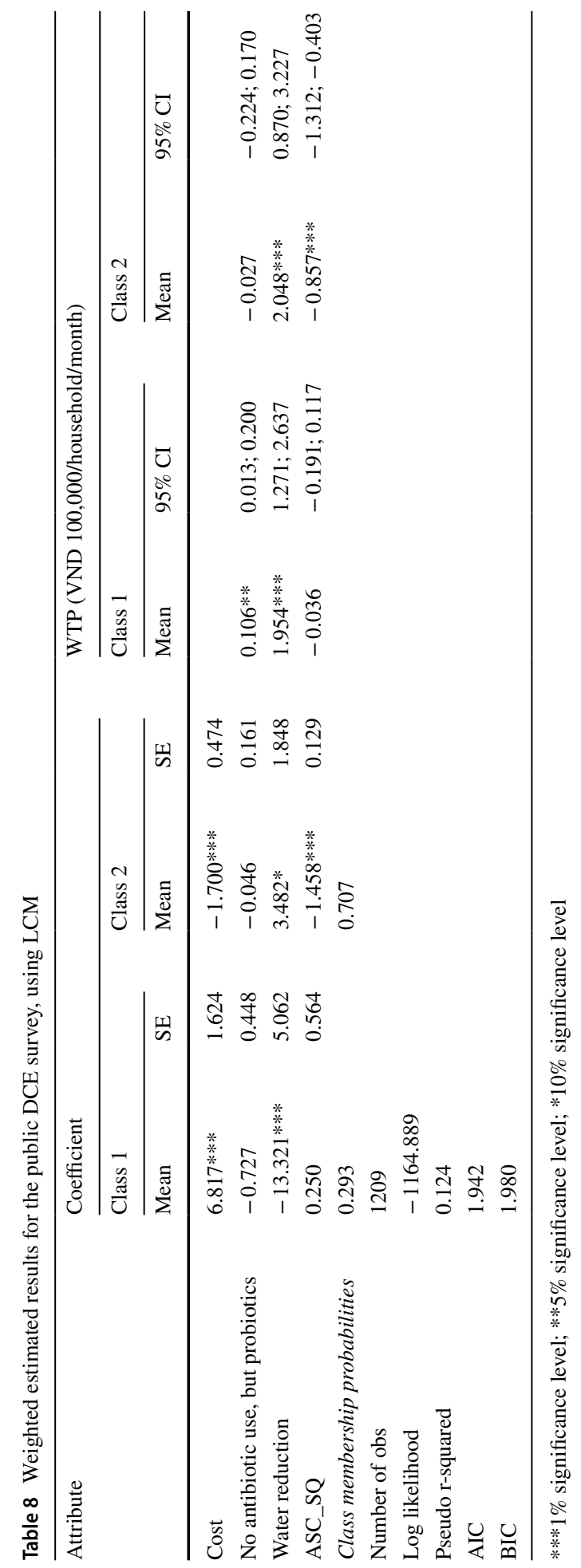




\section{References}

Anh PT et al (2010) Water pollution by intensive brackish shrimp farming in south-east Vietnam: causes and options for control. Agric Water Manag 97(6):872-882. https://doi.org/10.1016/j.agwat.2010.01.018

Barr RF, Mourato S (2009) Investigating the potential for marine resource protection through environmental service markets: an exploratory study from La Paz, Mexico. Ocean Coast Manag 52(11):568-577. https://doi.org/10.1016/j.ocecoaman.2009.08.010

Bennett R, Balcombe K (2012) Farmers' willingness to pay for a tuberculosis cattle vaccine. J Agric Econ 63(2):408-424. https://doi.org/10.1111/j.1477-9552.2011.00330.x

Bosma RH et al (2012) Factors affecting farmers' adoption of integrated rice-fish farming systems in the Mekong delta, Vietnam. Rev Aquacult 4:178-190. https://doi.org/10.1111/j.1753-5131.2012.01069.x

Budak F et al (2006) Consumer willingness to pay for organic sea bass in Turkey. Isr J Aquac Bamidgeh 58(2):116-123

Bui TD, Luong-Van J, Austin CM (2012) Impact of shrimp farm effluent on water quality in coastal areas of the world heritage-listed Ha Long Bay. Am J Environ Sci 8(2):104-116. https://doi.org/10.3844/ajess p.2012.104.116

Bui TD et al (2013) Assessment and monitoring of nutrient loading in the sediments of tidal creeks receiving shrimp farm effluent in Quang Ninh, Vietnam. Environ Monit Assess 185(10):8715-8731. https:// doi.org/10.1007/s10661-013-3207-2

Ca Mau DARD (2017) Report on the management, production and consumption of brackish shrimp in 2016 and orientations for the next years of Ca Mau province. Vietnamese: Báo cáo tình hình quản lý, sản xuất và tiêu thụ tôm nước lợ năm 2016 và định hướng phát triển những năm tiế'. Meeting of the development of shrimp industry in Vietnam. Ca Mau city. Department of Agriculture and Rural Development of Ca Mau province (Ca Mau DARD) - Ministry of Agriculture and Rural Development (MARD), pp 1-7

Campbell D, Erdem S (2019) Including opt-out options in discrete choice experiments: issues to consider. Patient. https://doi.org/10.1007/s40271-018-0324-6

Cisneros-montemayor $\mathrm{M}$ et al (2013) Extent and implications of IUU catch in Mexico' s marine fisheries. Mar Policy 39:283-288

Cisneros-montemayor AM et al (2016) Strategies and rationale for fishery subsidy reform. Mar Policy 69:229-236. https://doi.org/10.1016/j.marpol.2015.10.001

DAH (2017) Report on disease status of brackish water shrimp in 2016 and plan for disease prevention in 2017. Vietnamese: Tình hình dịch bệnh trên tôm nước lợ năm 2016 và kế hoạch phòng chống dịch bệnh năm 2017. Meeting of the development of shrimp industry in Vietnam. Ca Mau city. Department of Animal Health (DAH) - Ministry of Agriculture and Rural Development (MARD)

Do TN, Bennett J (2009) Estimating wetland biodiversity values: a choice modelling application in Vietnam's Mekong River Delta. Environ Dev Econ 14(02):163-186

Edwards P (2015) Aquaculture environment interactions: past, present and likely future trends. Aquaculture 447:2-14. https://doi.org/10.1016/j.aquaculture.2015.02.001

Engle CR et al (2017) Economics of sustainable intensification of aquaculture: evidence from shrimp farms in Vietnam and Thailand. J World Aquac Soc 48(2):227-239. https://doi.org/10.1111/jwas.12423

Espinosa-Goded M, Barreiro-Hurlé J, Ruto E (2010) What do farmers want from agri-environmental scheme design? A choice experiment approach. J Agric Econ 61(2):259-273

FAO (2019) Globefish highlights: a quarterly update on world seafood markets. January 2019 issue, with Jan-Sep 2018 statistics

Garrity DP, Akinnifesi FK, Ajayi OC (2010) Evergreen agriculture: a robust approach to sustainable food security in Africa. Food Secur 2:197-214. https://doi.org/10.1007/s12571-010-0070-7

Georgakopoulos G, Thomson I (2005) Organic salmon farming: risk perceptions, decision heuristics and the absence of environmental accounting. Account For 29:49-75. https://doi.org/10.1016/j.accfo r.2004.12.002

Greene WH, Hensher DA (2003) A latent class model for discrete choice analysis: contrasts with mixed logit. Transp Res Part B Methodol 37(8):681-698

Ha TTP, van Dijk H, Visser L (2014) Impacts of changes in mangrove forest management practices on forest accessibility and livelihood: a case study in mangrove-shrimp farming system in Ca Mau Province, Mekong Delta, Vietnam. Land Use Policy 36:89-101. https://doi.org/10.1016/j.landusepol .2013.07.002

Hai H (2017) Economic efficiency of high-tech shrimp farming method. Vietnamese Farmers Association-The Voice of Farmers, retrieved on 10 June 2017, from http://tnnn.hoinongdan.org.vn/sitepages/ news/1091/49441/hieu-qua-tu-mo-hinh-nuoi-tom-cong-nghe-cao 
Han K (2017) Shrimp culture development in Ca Mau province. Association of Science and Technology in Ca Mau province, retrieved on 16 Sept 2017, from http://lienhiephoikhkt.camau.gov.vn/tinh-hinh-phattrien-nuoi-tom-tinh-ca-mau.243

Hanley N, Mourato S, Wright RE (2001) Choi modelling approaches: a superior alternative for environmental valuation? J Econ Surv 15(3):435-462

Hardin G (1968) The tragedy of the commons. Science 162(3859):1243-1248

Hausman J, McFadden D (1984) Specification tests for the multinomial logit model. Econom J Econom Soc 52:1219-1240

Hempel E, Winther U, Hambrey J (2002) Shrimp farming and the environment: can shrimp farming be undertaken sustainably? Document prepared in collaboration with the World Bank. http://www.enaca .org/Shrimp/Publications/WBfinal.pdf

Hinkes C, Schulze-Ehlers B (2018) Consumer attitudes and preferences towards pangasius and tilapia: the role of sustainability certification and the country of origin. Appetite 127:171-181. https://doi. org/10.1016/j.appet.2018.05.001

Jackson C, Preston N, Thompson PJ (2004) Intake and discharge nutrient loads at three intensive shrimp farms. Aquac Res 35:1053-1061. https://doi.org/10.1111/j.1365-2109.2004.01115.x

Kaczan D, Swallow BM, Adamowicz WLV (2013) Designing payments for ecosystem services (PES) program to reduce deforestation in Tanzania: an assessment of payment approaches. Ecol Econ 95:20-30. https://doi.org/10.1016/j.ecolecon.2013.07.011

Klinger D, Naylor R (2012) Searching for solutions in aquaculture: charting a sustainable course. Annu Rev Environ Resour 37:247-276

Kumar G, Engle C, Tucker C (2018) Factors driving aquaculture technology adoption. J World Aquac Soc. https://doi.org/10.1111/jwas.12514

Lancaster KJ (1966) A new approach to consumer theory. J Political Econ 74(2):132-157

Lasner T, Hamm U (2011) Ecopreneurship in aquaculture-the adoption of organic fishfarming methods. Organic Is Life Knowl Tomorrow 2:72-75

Lusk JL (2003) Effects of cheap talk on consumer willingness-to-pay for golden rice. Am J Agric Econ 85(4):840-856

MARD (2017) Current status and solutions for developing shrimp industry in Vietnam. In Vietnamese: Hiện trạng và giải pháp phát triển ngành tôm Việt Nam. Meeting of the development of shrimp industry in Vietnam. Ca Mau city. Ministry of Agriculture and Rural Development (MARD)

McFadden D (1974) Conditional logit analysis of qualitative choice behavior. In: Zarembka P (ed) Frontiers in econometrics. Academic Press, NewYork, pp 105-142

Neiland AE et al (2001) Shrimp aquaculture: economic perspectives for policy development. Mar Policy 25:265-279

Ngoc PTA, Meuwissen MPM, Le TC et al (2016a) Adoption of recirculating aquaculture systems in large pangasius farms: a choice experiment. Aquaculture 460:90-97. https://doi.org/10.1016/j.aquacultur e.2016.03.055

Ngoc PTA, Meuwissen MPM, Tru LC et al (2016b) Economic feasibility of recirculating aquaculture systems in pangasius farming. Aquac Econ Manag 20(2):185-200. https://doi.org/10.1080/13657 305.2016.1156190

Olesen I et al (2010) Eliciting consumers' willingness to pay for organic and welfare-labelled salmon in a non-hypothetical choice experiment. Livest Sci 127(2-3):218-226. https://doi.org/10.1016/j.livsc i.2009.10.001

Páez-Osuna F (2001) The environmental impact of shrimp aquaculture: causes, effects, and mitigating alternatives. Environ Manage 28(1):131-140. https://doi.org/10.1007/s002670010212

Pan D et al (2016) Farmers' preferences for livestock pollution control policy in China: a choice experiment method. J Clean Prod 131:572-5582. https://doi.org/10.1016/j.jclepro.2016.04.133

Perdikaris C, Chrysafi A, Ganias K (2016) environmentally friendly practices and perceptions in aquaculture: a sectoral case-study from a mediterranean-based industry. Rev Fish Sci Aquac 24(2):113-125. https://doi.org/10.1080/23308249.2015.1112358

Pham TTH et al (2018) Analysis of antibiotic multi-resistant bacteria and resistance genes in the effluent of an intensive shrimp farm (Long An, Vietnam). J Environ Manag 214:149-156. https://doi. org/10.1016/j.jenvman.2018.02.089

Pomeroy R et al (2009) Small-scale marine fisheries policy in Vietnam. Mar Policy 33:419-428. https://doi. org/10.1016/j.marpol.2008.10.001

Pretty J et al (2011) Sustainable intensification in African agriculture. Int J Agric Sustain 9(1):5-24. https:// doi.org/10.3763/ijas.2010.0583 
Ruto E, Garrod G (2009) Investigating farmers' preferences for the design of agri-environment schemes: a choice experiment approach. J Environ Plann Manag 52(5):631-647. https://doi.org/10.1080/09640 560902958172

Scarpa R, Rose JM (2008) Design efficiency for non-market valuation with choice modelling: how to measure it, what to report and why? Aust J Agric Resour Econ 52(3):253-282

Senarath U, Visvanathan C (2001) Environmental issues in brackish water shrimp aquaculture in Sri Lanka. Environ Manag 27(3):335-348. https://doi.org/10.1007/s002670010153

Thao T (2017) Economic benefits of high-tech shrimp farming practices. Nhan Dan Newspaper, retrieved on 10 June 2017, from http://www.nhandan.com.vn/tphcm/thong-tin-kinh-te/item/32533202-giau-len-tumo-hinh-nuoi-tom-cong-nghe-cao.html

Trai NV, Momtaz S, Zimmerman K (2007) Water pollution concerns in shrimp farming in Vietnam: a case study of Can Gio, Ho Chi Minh city. Int J Environ Cult Econ Soc Sustain 3(2):9

Trung Chanh (2018) Lack of "capital" to invest in high-tech shrimp aquaculture. Vietnamese Sai Gon Times. https://www.thesaigontimes.vn/267938/Nuoi-tom-cong-nghe-cao-dang-ket-von.html

Weimin, M. (2017) Aquaculture production and trade trends: carp, tilapia and shrimp. In FMM/RAS/298: strengthening capacities, policies and national action plans on prudent and responsible use of antimicrobials in fisheries final workshop in cooperation with AVA Singapore. FAO

Xuan BB, Sandorf ED, Aanesen M (2017) Informing management strategies for a reserve: results from a discrete choice experiment survey. Ocean Coast Manag 145:35-43. https://doi.org/10.1016/j.oceco aman.2017.05.004

Yeboah FK, Lupi F, Kaplowitz MD (2015) Agricultural landowners' willingness to participate in a filter strip program for watershed protection. Land Use Policy 49:75-85. https://doi.org/10.1016/j.landu sepol.2015.07.016

Publisher's Note Springer Nature remains neutral with regard to jurisdictional claims in published maps and institutional affiliations. 